\title{
Occurrence and distribution of Perichaena (Trichiaceae, Myxomycetes] in the Brazilian Northeastern Region
}

\author{
Laise de Holanda Cavalcanti $1^{12^{\star}}$, Andrea Carla Caldas Bezerra', David Itallo Barbosa ${ }^{1,2}$, \\ Leandro de Almeida Neves Nepomuceno Agra ${ }^{3}$, Nestor Valente Powell', Vitor Xavier de Lima ${ }^{1,2}$ \\ and Antônia Aurelice Aurélio Costa'
}

Received: September 11, 2015

Accepted: November 27, 2015

\begin{abstract}
The known distribution of Perichaena calongei, P. chrysosperma, P. corticalis, P. depressa, P. microspora, P. pedata and P. vermicularis in the nine states that comprise Brazil's Northeast Region $\left(1,548,672 \mathrm{~km}^{2}\right)$ is presented herein, enhancing our understanding of the distribution of the genus Perichaena (Trichiaceae, Myxomycetes) in the Neotropics. This inventory encompasses a 100-year period (1914-2014), and analyzes material deposited in herbaria and collected by the authors. The collected material came from areas of thorny deciduous vegetation typical of the Caatinga biome and portions of savannah in the continent's interior, rainforests, restingas (tropical moist broadleaf forests found along Brazil's coastal spits) and mangroves of the Atlantic Forest biome along a coastal zone of approximately 3,000 km. Descriptions, illustrations, vegetational environments, microhabitats and distribution maps are given for each species. New records include Perichaena chrysosperma and P. depressa in the state of Maranhão, $P$. corticalis in the states of Bahia, Piauí, Rio Grande do Norte and Sergipe, P. calongei in the Northeast Region, and P. pedata in Brazil. This paper adds to the known types of macroclimates, elevation levels, vegetational environments and substrates for these species and provides a better understanding of their global distribution pattern.
\end{abstract}

Keywords: chorology, microhabitat, rainforest, steppical-savannah, Trichiales

\section{Introduction}

Initially proposed by E. M. Fries in 1817, the genus Perichaena currently encompasses 34 species, with just under half (48\%) being described between the years of 2000 and 2015, with type localities in countries of Africa, Asia, Europe, North, Central and South Americas (Novozhilov \& Schnittler 2000; Wang et al. 2000; Yamamoto et al. 2002; Liu et al. 2007; Novozhilov et al. 2008; Estrada-Torres et al. 2009; Lado et al. 2009; 2014; Mitchell et al. 2011; Basanta et al. 2013; Ronikier et al. 2013; Lado 2015; Novozhilov \& Stephenson 2015; Walker et al. 2015). In the Neotropics, where 16 species have already been noted, only $P$. calongei, P. megaspora and $P$. nigra have their type locality in South America (Lado \& Basanta 2008; Lado et al. 2009; 2014; Ronikier et al. 2013).

The genus is widely distributed in the Neotropical region, with records in 24 of the 31 countries where myxomycetes inventories have been conducted, with the greatest diversity being found in Mexico with 10 species, and Argentina and Ecuador, with six species each (Lado \& Basanta 2008; Estrada-Torres et al. 2009; Lado et al. 2009; 2014; McHugh 2009; Rojas et al. 2013; Ronikier et al. 2013). The first record of the occurrence of a species of Perichaena in Brazil was based on a specimen of P. chrysosperma col-

\footnotetext{
${ }^{1}$ Laboratório de Myxomycetes, Departamento de Botânica, Centro de Ciências Biológicas, Universidade Federal de Pernambuco, 50670-420, Recife, PE, Brazil ${ }^{2}$ Programa de Pós-Graduação em Biologia de Fungos, Departamento de Micologia, Centro de Ciências Biológicas, Universidade Federal de Pernambuco, 50670-420, Recife, PE, Brazil

${ }^{3}$ Programa de Pós-Graduação em Biologia Microbiana, Departamento de Fitopatologia, Instituto de Biologia, Universidade de Brasília, Campus Darcy Ribeiro, Asa Norte, 70910-900, Brasília, DF, Brazil

* Corresponding author: lhcandrade2@gmail.com
} 
lected in the first decade of the $20^{\text {th }}$ century in the state of Santa Catarina, in the Southern Region of Brazil (Jahn 1902; Cavalcanti \& Fortes 1994). Perichaena depressa has also been said to occur in the Southern Region of Brazil, having been found in the states of Santa Catarina and Rio Grande do Sul (Cavalcanti \& Fortes 1995; Cavalcanti 2015). In the Northern Region, the first record of this genus was made near the end of the $20^{\text {th }}$ century based on a collection of an unidentified species found at the Maracá Ecological Station, in the state of Roraima (Cavalcanti et al. 1999); recently, P. longipes was described as occurring on aerial litter in the same state (Walker et al. 2015). In the Southeast Region, P. depressa, P. chrysosperma, P. microspora and $P$. vermicularis are all found in the states of São Paulo and Rio de Janeiro (Torrend 1915; Maimoni-Rodella \& Gottsberger 1980; Hochgesand \& Gottsberger 1996; Cavalcanti 2015). Perichaena depressa and P. vermicularis are known to occur in the Central-West Region from collections conducted in Cerrado environments at IBGE's Ecological Reserve in the Federal District (Carvalho et al. 2011). Recently, Araujo et al. (2015) documented P. calongei in Brazil for the first time, based on specimens collected in the National Forest of Silvânia, a conservation unit of Cerrado in the state of Goiás.

The first mention of the occurrence of Perichaena in the Brazilian Northeast Region was based on a specimen of P. chrysosperma collected early in the $20^{\text {th }}$ century in Belém da Cachoeira in the state of Bahia (Torrend 1915). The genus has been recorded in almost all states of the Northeast Region with the exception of Maranhão (Cavalcanti 1974a; 2015; Cavalcanti \& Marinho 1985; Góes \& Cavalcanti 2002; Cavalcanti et al. 2006a; 2006b; Alves et al. 2010; Bezerra et al. 2014).

Despite these records, additional information regarding the species of Perichaena in Brazil is sparse with only Cavalcanti (1974a) supplying information on the types of environment, microhabitats and seasonal variation of the species that occur in the state of Pernambuco: P. chrysosperma, P. depressa, P. corticalis, P. microspora and P. vermicularis.

Aiming to expand up on the existing knowledge of the geographic and ecosystem distribution of myxomycetes in the Neotropics, this study presents the species of Perichaena found in the different states of the Northeast Region of Brazil and provides the vegetational environments they occupy based on records made between the years of 1914 and 2014.

\section{Materials and methods}

$$
\text { Study Region }
$$

One of South America's three major semi-arid areas is located in the Northeast Region of Brazil. It is characterized by low humidity, precipitation below evapotranspiration with irregular rainfall rhythms and extended periods of draught (Ab’Sáber 1999). Covering some 970,000 km², it encompasses almost all of the Caatinga biome present in the states of Alagoas, Bahia, Ceará, Paraíba, Pernambuco, Piauí and Sergipe, with average rainfall below $800 \mathrm{~mm} /$ year, an aridity index of up to 0.5 and high draught risk (MI 2005). Corresponding to climate, soil and topographical conditions, a wide variety of phytophisiognomies of xerophytic caatinga vegetation are found among the 1,113 municipalities of Brazil's semi-arid region (Prado 2003; Rodal et al. 2008), from dense arborous caatinga, where there is a predominance of Spondias tuberosa Arruda (Anacardiaceae), Myracrodruon urundeuva Allemão (Anacardiaceae), Schinopsis brasiliensis Engl. (Anacardiaceae), Sideroxylon obtusifolium (Roem. \& Schult.) T.D. Penn. (Sapotaceae), Tabebuia impetiginosa (Mart. ex DC.) Standl. (Bignoniaceae), Parapiptadenia zehntneri (Harms) M.P. Lima \& Lima (Fabaceae), Pterogyne nitens Tul. (Fabaceae), Ziziphus joazeiro Mart. (Rhamnaceae) and Cereus jamacaru DC. (Cactaceae), to creeping caatinga vegetation, where there is a predominance of Pilosocereus pachycladus F. Ritter (Cactaceae), Pilosocereus tuberculatus (Werderm.) Byles \& G.D. Rowley (Cactaceae), Eschweilera spp. (Lecythidaceae), Poeppigia procera C. Presl (Fabaceae), Dalbergia cearensis Ducke (Fabaceae), Piptadenia obliqua (Pers.) J.F. Macbr. (Fabaceae), Syagrus coronata (Mart.) Becc. (Arecaceae) and Jatropha mollissima (Pohl) Baill. (Euphorbiaceae). The Atlantic Forest biome can be found along the entire 3,317 $\mathrm{km}$ of Atlantic Ocean coastline and reaching inland almost $200 \mathrm{~km}$, also with a variety of different phytophisiognomies (Dense Ombrophilous Forest, Highland and Lowland Forests, Open Ombrophilous Forest, Mixed Ombrophilous Forest, Seasonal Deciduous and Semi-deciduous Forests, Steppe, Savannah and Steppical Savannah), with Restinga and Mangrove forests as associated ecosystems. Additionally, rainforest "islands", regionally known as Brejos de Altitude, are found in the semi-arid region at heights above $500 \mathrm{~m}$. The Pernambuco Center of Endemism can be found in this biome, and is comprised of all areas of Atlantic Forest north of the São Francisco River from the state of Alagoas to the state of Rio Grande do Norte (Uchoa \& Tabarelli 2002).

\section{Collection and identification}

The following herbaria were consulted in order to verify the occurrence of species of Perichaena Fries in the nine states of the Northeast Region of Brazil: HUEFS, ICN, IPA, JPB, SP, TEPB, UB, UFBA, UFP, URM (Thiers 2014). Exsiccate identification was confirmed or redetermined and the binomials updated according to Lado (2015). The inventory was completed with specimens and samples of substrates collected by the authors between 1968 and 2014 (ca. 200 study sites) in the states of Alagoas (AL), Bahia (BA), Ceará (CE), Maranhão (MA), Paraíba (PB), Pernambuco (PE), Piauí (PI), Rio Grande do Norte (RN) 
and Sergipe (SE) for preparing ca 6,500 moist chamber cultures (Härkönen 1981). Selected specimens were used to illustrate the sporocarps and taxonomically significant microstructures. Keys, illustrations and descriptions by Martin \& Alexopoulos (1969); Farr (1976); Lado \& Pando (1997) and Poulain et al. (2011) were used for species identification. Localities and corresponding geographical coordinates (based on field notes and exsiccate labels) were employed to construct distribution maps for the species using the QGIS 2.2 program.

\section{Summary data on collecting localities in the nine states}

Alagoas (AL): 1 - São José da Tapera municipality, $09^{\circ} 33^{\prime} 28^{\prime \prime} \mathrm{S}$ and $37^{\circ} 22^{\prime} 51^{\prime \prime} \mathrm{W}$. Biome: Caatinga. Herbarium: URM.

Bahia (BA): 2 - Private Reserve of Natural Heritage (RPPN) Serra do Teimoso, Jussari municipality, $15^{\circ} 09^{\prime} 472^{\prime \prime}$ $S$ and $39^{\circ} 31^{\prime} 737^{\prime \prime} \mathrm{W} ; 3$ - Campus of the Universidade Estadual de Feira de Santana, Feira de Santana municipality, $12^{\circ} 16^{\prime} 01^{\prime \prime} S$ and $38^{\circ} 58^{\prime} 01^{\prime \prime} \mathrm{W}$; 4 - Jussiape municipality, $1^{\circ} 31^{\prime} 01^{\prime \prime} S$ and $41^{\circ} 35^{\prime} 34^{\prime \prime} \mathrm{W} ; 5$ - Campo Formoso municipality, $10^{\circ} 30^{\prime} 32^{\prime \prime S}$ and $40^{\circ} 19^{\prime} 15^{\prime \prime} \mathrm{W} ; 6$ - Brejo do Tamanduá municipality, $10^{\circ} 25^{\prime} 36^{\prime \prime} \mathrm{S}$ and $40^{\circ} 15^{\prime} 51^{\prime \prime} \mathrm{W}$; 7 - Jaguarari municipality, $10^{\circ} 15^{\prime} 36^{\prime \prime} \mathrm{S}$ and $40^{\circ} 11^{\prime} 45^{\prime \prime} \mathrm{W}$; 8 - Rio de Contas municipality, $13^{\circ} 34^{\prime} 44^{\prime \prime} \mathrm{S}$ and $41^{\circ} 48^{\prime} 39^{\prime \prime} \mathrm{W}$; 9 - Environmental Protection Area (APA) of Marimbus, Lençois municipality, $12^{\circ} 33^{\prime} 46^{\prime \prime}$ S and $41^{\circ} 23^{\prime} 24^{\prime \prime} \mathrm{W}$. Biomes: Atlantic Forest; Caatinga, including Brejo de Altitude. Herbaria: HUEFS; UFP.

Ceará (CE): 10 - Sobral municipality,03 $40^{\prime} 26^{\prime \prime} S$ and 40¹4'20"W. Biome: Caatinga. Herbarium: UFP.

Maranhão (MA): 11 - Bacanga Ecological Station, São Luis municipality, $02^{\circ} 31^{\prime} 48^{\prime \prime}$ S and $44^{\circ} 18^{\prime} 10^{\prime \prime} \mathrm{W}$. Biome: Atlantic Forest. Herbarium: UFP.

Paraíba (PB): 12 - RPPN Pau Ferro Forest, Areia municipality, $06^{\circ} 57^{\prime} 46^{\prime \prime}$ ' and $35^{\circ} 42^{\prime} 31^{\prime \prime} \mathrm{W} ; 13$ - Campus of the Universidade Federal da Paraíba, João Pessoa municipality, $07^{\circ} 05^{\prime} 00^{\prime \prime} \mathrm{S}$ and $34^{\circ} 50^{\prime} 00^{\prime \prime} \mathrm{W} ; 14$ - Mata do Buraquinho Forest Reserve, João Pessoa municipality. 15 - Guaribas Biological Reserve, Mamanguape municipality, 06 50 '20"S and $35^{\circ} 07^{\prime} 33^{\prime \prime} \mathrm{W}$. Biomes: Atlantic Forest; Caatinga (Brejo de Altitude). Herbaria: JPB; UFP.

Pernambuco (PE): 15 - Recife city, urban parks, home gardens and backyards, $08^{\circ} 03^{\prime} 14^{\prime \prime} \mathrm{S}$ and $34^{\circ} 52^{\prime} 51^{\prime \prime} \mathrm{W} ; 16$ Dois Irmãos State Park, Recife municipality, 08 $00^{\prime} 33^{\prime \prime S}$ and $34^{\circ} 56^{\prime} 37^{\prime \prime} W ; 17$ - Curado Botanical Garden, Recife, $08^{\circ} 04^{\prime} 36^{\prime \prime} \mathrm{S}$ and $34^{\circ} 58^{\prime} 03^{\prime \prime} \mathrm{W}$; 18 -Olinda city, home gardens and backyards, $08^{\circ} 00^{\prime} 32^{\prime \prime} \mathrm{S}$ and $34^{\circ} 51^{\prime} 18^{\prime \prime} \mathrm{W}$; 19 - Enseadinha beach, Rio Doce beach, 07 57'24'S and $34^{\circ} 49^{\prime} 00^{\prime \prime} \mathrm{W} ; 20$ - Chico Science mangrove, Olinda municipality, $08^{\circ} 33^{\prime} 43^{\prime \prime}$ 'S and $34^{\circ} 86^{\prime} 32^{\prime \prime} \mathrm{W}$; 21 - Janga (restinga forest), Paulista municipality, $7^{\circ} 56^{\prime} 68^{\prime \prime} \mathrm{S}$ and $34^{\circ} 51^{\prime} 54^{\prime \prime} \mathrm{W}$; 22 - Charles Darwin Ecological Refuge, Igarassu munici- pality, $07^{\circ} 48^{\prime} 55^{\prime \prime} \mathrm{S}$ and $34^{\circ} 57^{\prime} 16^{\prime \prime} \mathrm{W} ; 23$ - Mata do Estado Reserve, São Vicente Ferrrer municipality, 07 $35^{\prime} 00^{\prime \prime} S$ and 35'30’00"; 24 - Tapacurá Ecological Reserve, São Lourenço da Mata municipality, $08^{\circ} 03^{\prime} 27^{\prime \prime} \mathrm{S}$ and $35^{\circ} 13^{\prime 2} 20^{\prime \prime} \mathrm{W}$; 25 - Gurjau Ecological Reserve, Cabo de Santo Agostinho municipality, $8^{\circ} 28^{\prime} 66^{\prime \prime}$ S and $35^{\circ} 03^{\prime} 50^{\prime \prime} \mathrm{W} ; 26$ - Saltinho Biological Reserve, Rio Formoso municipality, $8^{\circ} 42^{\prime} 00^{\prime \prime} \mathrm{S}$ and $35^{\circ} 10^{\prime} 00^{\prime \prime} \mathrm{W}$; 27 - Rio Formoso mangrove, Rio Formoso municipality, 08 $39^{\prime} 50^{\prime \prime} S$ and $35^{\circ} 09^{\prime} 32^{\prime \prime} W ; 28$ - Serra de Ororubá, Pesqueira municipality, $8^{\circ} 25^{\prime} 8^{\prime \prime} \mathrm{S}$ and $37^{\circ} 3^{\prime} 14^{\prime \prime} \mathrm{W}$; 29 -Vale do Catimbau National Park, Buique municipality,

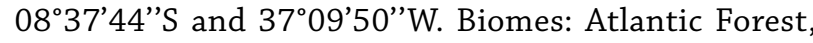
including Costal tablands, Restingas and Mangroves; Caatinga, including Brejos de Altitude; Cerrado spots. Herbaria: IPA, UFP, URM.

Piauí (PI): 30 - Sete Cidades National Park, Piripiri municipality, $04^{\circ} 16^{\prime} 22^{\prime \prime} S$ and $41^{\circ} 46^{\prime} 37^{\prime \prime} \mathrm{W}$; 31 - Zoobotanic Park, Teresina municipality, $05^{\circ} 05^{\prime} 20^{\prime \prime} \mathrm{S}$ and $42^{\circ} 48^{\prime} 07^{\prime \prime} \mathrm{W}$; 32 -Serra da Capivara National Park, São Raimundo Nonato municipality, $05^{\circ} 05^{\prime} 20^{\prime \prime} \mathrm{S}$ and $42^{\circ} 48^{\prime} 07^{\prime \prime} \mathrm{W}$; 33 - Serra Branca municipality, $06^{\circ} 04^{\prime} 00^{\prime \prime} \mathrm{S}$ and $41^{\circ} 27^{\prime} 00^{\prime \prime} \mathrm{W}$. Biomes: Caatinga; Cerrado spots. Herbaria: TEPB; UFP.

Rio Grande do Norte (RN): 34 - RPPN Estrela Forest, Formosa Bay municipality, $06^{\circ} 24^{\prime} 33^{\prime \prime}$ S and $34^{\circ} 59^{\prime} 25^{\prime \prime} \mathrm{W}$; 35 - Seridó Ecological Reserve, Serra Negra do Norte municipality, $06^{\circ} 35^{\prime} 29^{\prime \prime}$ S and $37^{\circ} 15^{\prime} 41^{\prime \prime} \mathrm{W} ; 36$ - Dunas State Park, Natal municipality, $05^{\circ} 49^{\prime} 12^{\prime \prime} \mathrm{S}$ and $35^{\circ} 11^{\prime} 16^{\prime \prime} \mathrm{W}$. Biomes: Atlantic Forest including Restinga; Caatinga. Herbarium: UFP.

Sergipe (SE): 37 - Pacatuba municipality $10^{\circ} 27^{\prime} 12^{\prime \prime S}$ and $36^{\circ} 39^{\prime} 05^{\prime}$ W. 38 - Serra de Itabaiana National Park, Areia Branca municipality, $10^{\circ} 45^{\prime} 29^{\prime \prime S}$ and $37^{\circ} 18^{\prime} 45^{\prime \prime} \mathrm{W}$. Biome: Atlantic Forest including Mangroves. Herbarium: UFP.

\section{Results and Discussion}

In the six herbaria where exsiccates of Perichaena were found, 318 specimens of different levels of preservation and corresponding to seven species occurring in one or more states of Brazil's Northeast Region, were assessed. A list of voucher specimens, substrata and localities is provided in Tab. S1 in Supplementary material. We provide the first records of Perichaena chrysosperma and P. depressa for the state of Maranhão, P. corticalis for Bahia, Piauí, Rio Grande do Norte, and Sergipe, P. calongei for the Northeast Region, and P. pedata for Brazil.

Among the species of Perichaena recorded for Brazil's Northeast Region, P. depressa shows the widest distribution, with records in all states except Alagoas, while the remaining species were recorded from only one or two of the nine states. In this region of the country, these species are distributed among environments of savannah, steppical-savannah (=caatinga), rupestrian fields, highland and lowland forests, dense and open ombrophilous forests, semi-deciduous seasonal forests, riparian forests, coastal 
tablelands, restinga and mangrove forests, but they were most abundant in rainforests (Tab. 1). In the several vegetational environments where they are found, on the most part, they sporulate on decomposing tree trunks, behaving also as corticolous, fimicolous, floricolous, foliicolous, lichenicolous, myceticolous and succulenticolous (Tab. 2).

Perichaena, and the seven species of this genus that occur in the Northeast Region of Brazil, are described and commented on below.

\section{Perichaena Fr., Syst. Gasteromyc.: 11. 1817.}

Typus: Perichaena populina Fr.

Sporocarps sessile or stalked with globose, subglobose or flat sporotheca, to plasmodiocarps. Peridium double, rarely simple. Stalk, when present, blackened, with refuse material, more rarely white, with calcium deposits. Capillitium abundant or scanty, filaments hollow, nonbirefringent, simple or branched, almost smooth, warted or spiny, often constricted. Spores in mass yellow, orangecolored or ochraceous, yellow by transmitted light, globose, subglobose to ovate, rarely polygonal, warted, spinose or reticulated (Lister1925; Martin \& Alexopoulos 1969; Novozhilov et al. 2008; Poulain et al. 2011; Novozhilov \& Stephenson 2015).

For some authors, such as Eliasson (1977; 2015), Keller \& Eliasson (1992) and Novozhilov et al. (2008), species with capillitium scanty or absent indicate a possible affinity between Perichaena and Licea; however, this relationship was not supported in recent molecular phylogenetic analyses that showed the genus Perichaena to be monophyletic (Fiore-Donno et al. 2013).

1. Perichaena calongei Lado, D. Wrigley and Estrada, in Lado, Wrigley, Estrada, García Carvajal, Aguilar and Hernández-Crespo, Anales Jard. Bot. Madrid 66S1:63-70. 2009. Fig. 1A-E.

Hypothallus conspicuous. Sporocarp disperse, subsessile. Sporotheca subglobose, amber to orange yellow, 200-
$800 \mu \mathrm{m}$ diam. Peridium opens into polygonal plates along predefined lines, remaining at the base as an irregular calyculus; external layer coriaceous, inner layer membranous, yellowish, firmly adhering to the external layer. Capillitium tubular, filaments branched, rare free ends, diameter irregular $(2-4 \mu \mathrm{m})$, yellow, with spines, grains and/or reticules irregularly distributed with triangular, ellipsoid or fusiform expansions. Spores in mass orangeyellow, subglobose, yellow by transmitted light, densely warted, 10-13 $\mu \mathrm{m}$ diam.

Distribution in the Northeast Region of Brazil: BA - 2, PE - 27, RN -35 (this paper).

Described by Lado et al. (2009), P. calongei occurs in different localities distributed among the five states in northwestern Argentina in arid environments at high elevations; all specimens were obtained from the base of dead Puya sp. (Bromeliaceae) leaves, directly in the field or from moist chambers with a $\mathrm{pH}$ varying from neutral to slightly alkaline. The species was not found on other substrates or in cultures prepared with the remains of native plants from the same areas, which led the authors to conclude that microhabitat requirements are offered only by this type of Bromeliaceae.

Perichaena calongei is rare in Brazil, with only three records for the Northeast Region (this paper) and one for the National Forest of Silvânia (895-900 m), in the Central-West Region, found on decaying leaves and bark samples collected in a gallery forest and placed in moist chamber cultures (Araujo et al. 2015). Specimens were obtained from moist chambers assembled with lianas from the dense submontane ombrophilous forest in Bahia (RPPN Serra do Teimoso), bark of living trees on dense ombrophilous lowland forest (Saltinho Biological Reserve, PE) and with forest litter from Restinga forest (RPPN Estrela Forest), along the seashores of Rio Grande do Norte (Tabs. 1-2). The data obtained in the present study increases the known types of macroclimates, elevations, vegetational environments and substrates for this

Table 1. Vegetational environments in which species of Perichaena Fr. occur in Brazil's Northeast Region.Rup. = Rupestrian fields. Mang. = Mangrove forest. Sav. $=$ Savannah. Caat. $=$ Caatingas. Urb. $=$ Urban areas. Forests: $1-$ Dense ombrophilous of the lowlands; $2-$ Sub-montane dense ombrophilous $3-$ Seasonal semi-deciduous; 4 - Restinga. 5 - Pluvio-Nebular Tropical Subperennial 16 - Pre-Amazonian

\begin{tabular}{|c|c|c|c|c|c|c|c|c|c|c|c|}
\hline \multirow{3}{*}{ Species } & \multicolumn{11}{|c|}{ Vegetational environments } \\
\hline & \multirow{2}{*}{ Rup. } & \multirow{2}{*}{ Mang. } & \multicolumn{6}{|c|}{ Forests } & \multirow{2}{*}{ Sav. } & \multirow{2}{*}{ Caat. } & \multirow{2}{*}{ Urb. } \\
\hline & & & 1 & 2 & 3 & 4 & 5 & 6 & & & \\
\hline P. calongei & & & & + & & + & & & & & \\
\hline P. chrysosperma & + & & + & + & + & + & & + & & + & + \\
\hline P. corticalis & & & + & & + & & & & & + & + \\
\hline P. depressa & & + & + & & & & + & & + & + & + \\
\hline P. microspora & & & + & & + & & & & & & \\
\hline P. pedata & & & & + & + & & & & & & \\
\hline P. vermicularis & & & & & + & & & & & & + \\
\hline
\end{tabular}


Table 2. Microhabitats in which species of Perichaena Fr. occur in Brazil's Northeast Region

\begin{tabular}{|l|l|}
\hline Microhabitat & \multicolumn{1}{c|}{ Species } \\
\hline Corticolous & P. chrysosperma; P. corticalis; P. depressa; P. pedata; P. vermicularis. \\
\hline Fimícolous & P. corticalis; P. depressa. \\
\hline Folíícolous & P. calongei; P. chrysosperma; P. corticalis; P. depressa; P. microspora. \\
\hline Floricolous & P. chrysosperma; P. corticalis; P. depressa. \\
\hline Lignicolous & P. calongei; P. chrysosperma; P. corticalis; P. depressa; P. vermicularis. \\
\hline Lichenicolous & P. corticalis. \\
\hline Myceticolous & P. corticalis. \\
\hline Succulenticolous & P. chrysosperma; P. corticalis; P. depressa. \\
\hline
\end{tabular}

species and contributes to a better understanding of its global distribution pattern.

\section{Perichaena chrysosperma (Curr.) Lister, Monogr.} Mycetozoa: 196. 1894. Fig. 1A, F-I.

Hypothallus conspicuous. Plasmodiocarps disperse, horseshoe, ring or linear-shaped, (0.4)-0.6-1.2 (-1.6) mm wide up to $0.5 \mathrm{~cm}$ long,occasionally exhibiting globose sporocarp, sessile to subsessile, nut brown-yellow, nutbrown-red or blackened nut-brown. Peridium double, pale yellow, external layer cartilaginous, inner layer membranous, smooth or slightly wrinkled; dehiscence irregular. Capillitium tubular, pale yellow, filaments 3-4 $\mu \mathrm{m}$ diam., frequently covered with spines up to $5 \mu \mathrm{m}$ long, sparse and sometimes with some rounded tips. Spores in mass pale yellow, subglobose, varying slightly from yellow to light nut-brown by transmitted light, distinctly warted, (9-) 10-11 (-12) $\mu \mathrm{m}$ diam.

Distribution in the Northeastern Region of Brazil: BA 2, PB - 12; PE - 16; 17; 23; 19; 29; 30; 25; 222; RN - 35; 36; SE - 39 (Cavalcanti 2015). MA - 11 (this paper).

In Brazil's Northeast Region, P. chrysosperma can be found in natural environments as well as in urban parks, backyards and home gardens, sporulating in almost all months of the year, but reaching its peak in the rainy season (Cavalcanti 1974a). It is mostly lignicolous, however, it occupies other microhabitats as well, developing on the cortex of living trees, on ground litter and on succulent and plant inflorescences (Tab. 2). It is distributed among different municipalities in the state of Bahia, Maranhão (first record), Paraíba, Pernambuco, Rio Grande do Norte and Sergipe, in pre-Amazonian forest environments, lowland dense ombrophilous forests, semi-deciduous seasonal forests, restinga forests, caatinga and rupestrian fields (Tab. 1). This is the first record of this species in a pre-Amazonian forest environment, as well as in an extremely dry environment such as the caatinga, in the microregion of Serido Ocidental, in the state of Rio Grande do Norte.
3. Perichaena corticalis (Batsch) Rostaf., Sluzowce Monogr. 293. 1875. Fig. 2A-E.

Hypothallus conspicuous, membranous, usually continuous for a group of sporocarps. Sporocarp sessile, with a slightly constricted base. Sporotheca subglobose, 0.4-0.9 $\mathrm{mm}$ diam., yellowish, reddish nut-brown or yellowish nut-brown. Peridium double, external layer cartilaginous, opaque, thickened with granules, inner layer membranous, translucent, light yellow and smooth; dehiscence circumscissile by a sinuous line slightly above the base of the sporotheca. Capillitium scanty, devoid of ramifications, filaments pale yellow. Spore in mass golden-yellow to orange, globose to oval-shaped, pale yellow by transmitted light, warted, (10-) 11 (-13) $\mu \mathrm{m}$ diam.

Distribution in the Northeast Region of Brazil: AL - 1, PB - 12; 13, PE - 16; 17; 29. (Bezerra et al. 2014; Cavalcanti 2015). BA - 5, 6, 7, PI - 33, RN - 36, SE - 39 (this paper).

In Brazil, the published records of this species were restricted to the Northeast Region, occurring in the states of Alagoas (Bezerra et al. 2014), Pernambuco (Farr 1960), Paraíba and Piauí (Cavalcanti 2015). The present study includes specimens collected in the Mesoregion of North Central Bahia (UFP 43420 and UFP 43447), and in the states of Sergipe and Rio Grande do Norte, in the wilderness of Seridó. In the environments in which it was recorded, P. corticalis occupies different microhabitats and can be lignicolous, foliicolous, corticolous or fimicolous in different types of vegetation from Caatinga (UFP 43428; UFP 43433 and UFP 43435), for which there were no previous occurrence records, to coastal rainforests (Tabs. 1-2).

4. Perichaena depressa Lib., Pl. Crypt. Arduenna 378. 1837. Fig. 2A, F-K.

Hypothallus inconspicuous. Sporocarp sessile, aggregated, seldom dispersed. Sporotheca strongly flattened (0.9-) 1.0-1,5 (-1.7) mm diam., yellowish brown, reddish brown or blackened brown with a yellow dehiscence line very close to its base. Peridium double, external layer cartilaginous, firm, opaque, thickened with granules, in- 

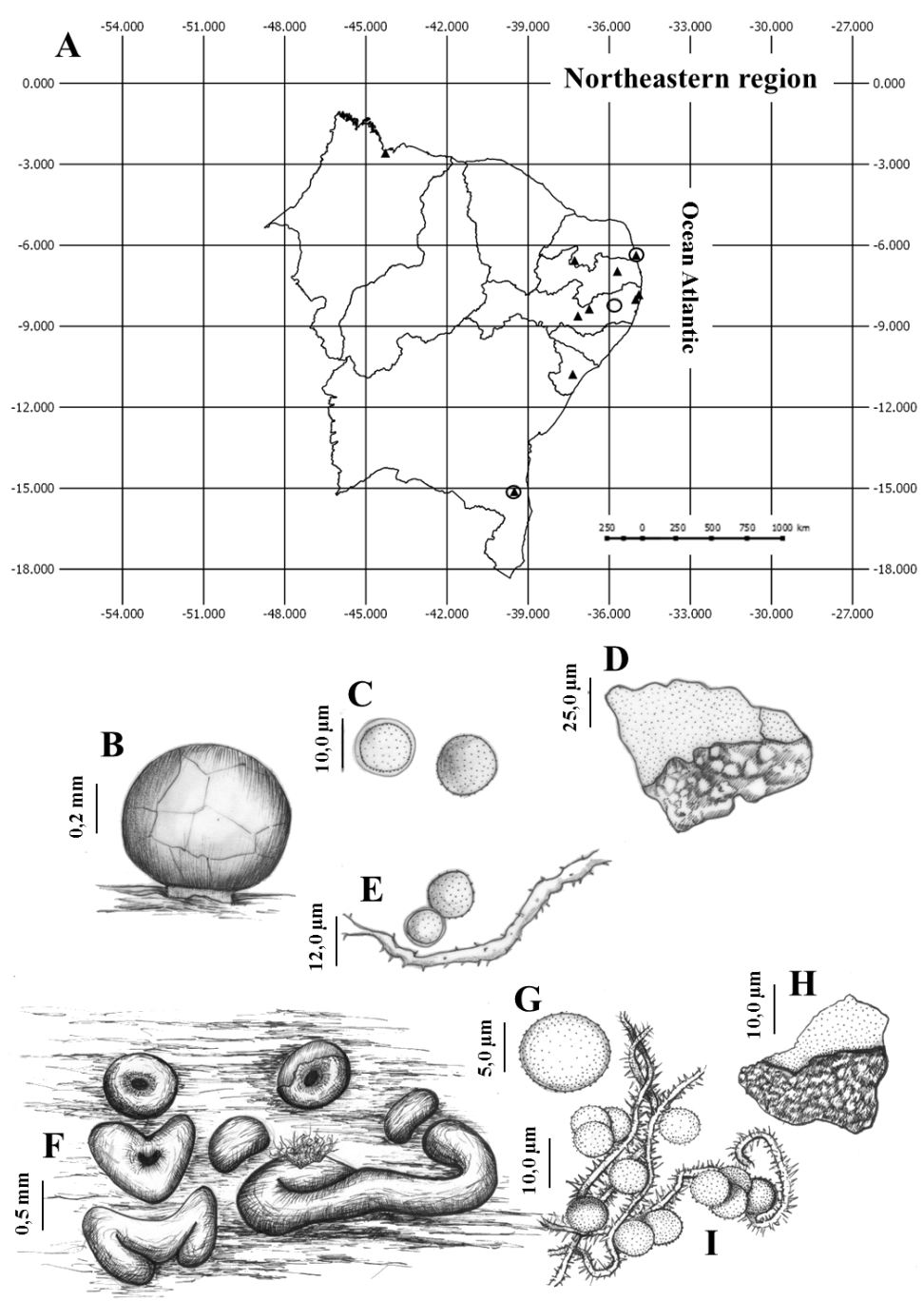

Figure 1. A. Geographical distribution of Perichaena calongei and P. chrysosperma in the Northeast Region of Brazil. B-E Perichaena calongei: B. Sporocarp. C. Spores. D. Inner surface of the peridium. E. Capillitium and spores. F-I Perichaena chrysosperma: F. Plasmodiocarp. G. Spore. H. Inner surface of the peridium. I. Capillitium and spores.

ner layer membranous, translucent, brilliant, light yellow; dehiscence circumscissile along the line formed just by the inner layer of the peridium. Capillitium tubular, abundant, filaments branched, (1.8-) 2-2.5 (-3.2) $\mu$ m diam., minutely warted or, more frequently, with regularly spaced constrictions. Spores in mass golden-yellow or orange-colored, subglobose, pale yellow by transmitted light, warted, 9-10 $\mu \mathrm{m}$ diam.

Distribution in the Northeast Region of Brazil: AL - 1 , BA - $5 ; 6 ; 8$; PB - 14; 12; PE - 16; 21; 20; 17; 23; 29; 26; 28 ; 30; 31; PI - 31; 32; 33; RN - 35; 36; 7; SE - 38; 39 (Bezerra et al. 2014; Cavalcanti 2015). CE - 10; MA- 11 (this paper).

Despite its wide distribution in Brazil's northeast, the occurrence of $P$. depressa had not yet been recorded in the state of Maranhão, where it was collected in a preAmazonian rainforest environment, as well as in a steppical savannah environment with annual rainfall $<500 \mathrm{~mm}$ (municipality of Campo Formoso, BA) and in natural areas of Seridó, in Rio Grande do Norte.

Perichaena depressa is predominantly lignicolous (40\% of the samples), however, it is also found in special microhabitats occasionally as a floricolous or a succulenticolous species, but it is also one of the two species of this genus present in the studied collections that is fimicolous in Brazil's Northeast Region (Tab. 1).

5. Perichaena microspora Penz. \& Lister, in Penzig, Myxomyc. Fl. Buitenzorg 76. 1898. Fig. 3A-E.

Hypothallus inconspicuous. Plasmodiocarp of varying length, sometimes reticulated, 250-350 $\mu \mathrm{m}$ diam., pink-salmon to ochraceous. Peridium simple, yellow, membranose, inner surface with grains of refused material close to the base of the sporocarp. Capillitium loose, yellowish-pink, filaments almost hyaline by transmitted 

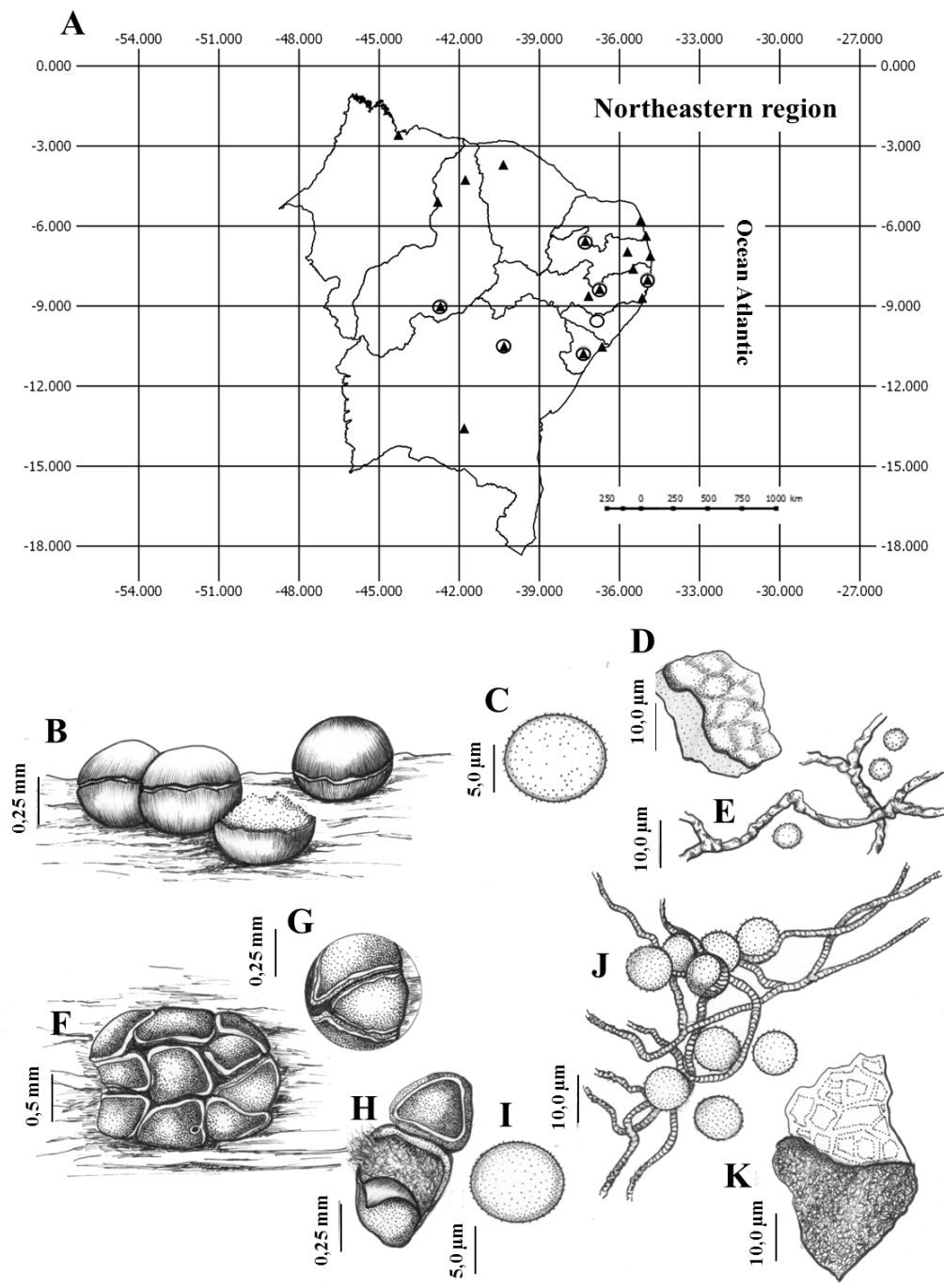

Figure 2. A. Geographical distribution of Perichaena corticalis and P. depressa in the Northeast Region of Brazil. B-E Perichaena corticalis: B. Sporocarp; C. Spore. D. Inner surface of the peridium. E. Capillitium and spores; F-K Perichaena depressa: F-H. Sporocarps. I. Spore. J. Capillitium and spores. K. Inner surface of the peridium.

light, 1.5-2 $\mu \mathrm{m}$ diam., up to $5 \mu \mathrm{m}$ diam. at ramification points, densely spiny ( $2 \mu \mathrm{m}$ in length.). Spores in mass yellowish-pink, subglobose, light yellow by transmitted light, spiny, 6-7 $\mu \mathrm{m}$ diam.

Distribution in the Northeast Region of Brazil: BA (Torrend 1916); PE - 18 (Cavalcanti 2015).

With few records in European, Asiatic and North American countries, P. microspora is rare in the Neotropics, with known occurrences only in Cuba, Costa Rica and Brazil (Lado \& Basanta 2008; Cavalcanti 2015).

Torrend (1916) included P. microspora in his list of species for the state of Bahia. However, exsiccates were not located in the collection of the URM herbarium, where almost all collections made by him in Brazil were deposited. Exsiccate UFP 5070 was collected in Pernambuco in 1980 in a semi-deciduous seasonal forest environment, on dead leaves (Tabs. 1-2) and identified in the same year by one of the authors. It was recorded in the Southeast Region for the first time by Cavalcanti (2015), based on an exsiccate deposited at the MA - fungi Herbarium, collected also in a semi-deciduous seasonal forest environment in the state of São Paulo by C. Lado \& R. C. Maimoni-Rodella.

6. Perichaena pedata (Lister \& G. Lister) Lister ex E. Jahn, Ber. Deutsch. Bot. Ges. 36: 667. 1919. Fig. 3A, F-I.

Hypothallus inconspicuous. Sporocarp solitary, stalked. Stalk dark brown, cylindrical, grainy, 0.1-0.3 mm long. Sporotheca globose, yellowish-orange, 0.1-0.5 mm diam. Peridium simple, persistent at the base, yellowishorange, containing grains of refused material; dehiscence apical, irregular. Capillitium abundant, yellow, elastic, filaments branched, marked by short spines (2-3 $\mu$ m long). Spores in mass yellow, globose, uniformly warted, yellow by transmitted light, 10-12 $\mu \mathrm{m}$ diam. 
Distribution in the Northeast Region of Brazil: First record for Brazil. BA - 2; PE - 22; PB - 15 (this paper).

This species was originally described by $A$. Lister and G. Lister as a variety of $P$. variabilis (= P. vermicularis), based in seven specimens found in 1902 on dead leaves, in Lime Regis, a coastal town in West Dorset, England. It was also considered a variety of $P$. chrysosperma (Torrend 1908; Lister 1925) but Jahn (1919) treated it as a distinct species, as early noted by Lister \& Lister (1904). In the Neotropics P. pedata has been previously reported from Mexico, Costa Rica and Ecuador (Lado \& Basanta 2008) and this is its first record from Brazil, based in specimens developed on bark of living trees in a moist chamber culture (RPPN Serra do Teimoso, BA; Guaribas Biological Reserve, PB; Charles Darwin Ecological Refuge, PE).
7. Perichaena vermicularis (Schwein.) Rostaf., Sluzowce Monogr. 34. 1876. Fig. 3A, J-M.

Hypothallus inconspicuous. Plasmodiocarp, rarely sporocarp, globose, sessile, grouped or isolated, reddishbrown to ochraceous, total height 0.3-0.5 (-0.8) $\mathrm{mm}$. Peridium double; dehiscence irregular, persistent at the base; external layer containing refused material, inner layer membranous, papillose. Capillitium tubular, scanty, filaments 2-3 $\mu \mathrm{m}$ diam., branched, smooth either with short spines or small warts. Spores in mass yellow-ochraceous, globose to ellipsoid, yellow almost hyaline by transmitted light, minutely spiny, 8-9 (11) $\mu \mathrm{m}$ diam.

Distribution in the Northeast Region of Brazil: BA - 9; PE - 15; 18 (Cavalcanti 2015).

The collection of the UFP herbarium has nine specimens of $P$. vermicularis, predominantly collected on the
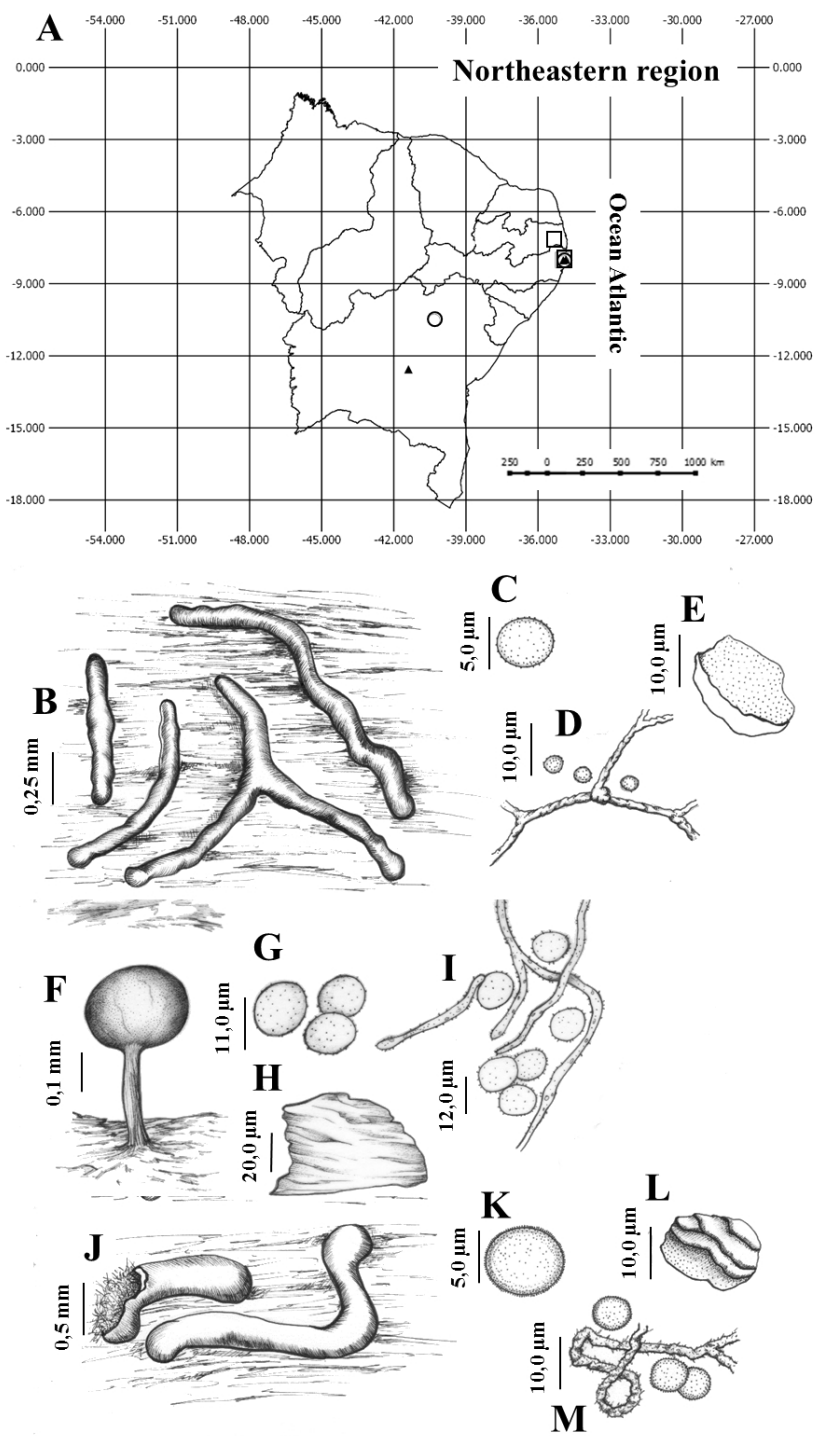

Figure 3. A. Geographical distribution of Perichaena microspora, P. pedata and P. vermicularis in the Northeast Region of Brazil. B-E Perichaena microspora: B. Plasmodiocarp. C. Spore. D. Capillitium and spores. E. Inner surface of the peridium; F-I Perichaena pedata: F. Sporocarp. G. Spores. H. Inner surface of the peridium. I. Capillitium and spores; J-M Perichaena vermicularis: J. Plasmodiocarp; K. Spore. L. Inner surface of the peridium. M. Capillitium and spores. 
cortex of living trees and occasionally on dead tree trunks in parks and residential gardens (Tabs. 1-2).

The occurrence of $P$. vermicularis on the cortex of living trees has been recorded by different authors, such as Basanta (1998, on the cortex of Quercus ilex, Fagaceae) in Spain and by Cavalcanti (1974b) on Vochysia tucanorum (Vochysiaceae) and Aspidosperma tomentosum (Apocynaceae) in the cerrado of Emas, São Paulo.

The species is uncommon in the Northeast Region, with a few records in the municipalities of Recife and Olinda, in Pernambuco (Cavalcanti 1974a; Bezerra \& Cavalcanti 2007) and in Lençóis, BA, in the Diamantina Plateau (Gusmão et al. 2005). In Pernambuco, all exsiccates were collected in an urban environment (Tab. 1). Specimens collected on living tree trunks of Terminalia catappa (Combretaceae), in Olinda, PE, about $1 \mathrm{~km}$ from the coastline, showed small plasmodiocarps, with scanty capillitium and with spores of smaller diameter than normally described for the species, as also observed by Lado \& Pando (1997). The remaining characteristics are typical for the species. In Bahia, it was found in the APA of Marimbus (HUEFS 84703), that encompasses a variety of ecosystems such as rupestrian fields, savannahs, steppical savannahs and seasonal forests, aside from marimbús, marsh-like environments into which most of the water of the Diamantina Plateau is drained (Tab. 1). Aside from the Northeast Region, P. vermicularis has been known to occur towards the Central-West Region (Federal District) in an environment of Cerrado and in the Southeast Region (SP), in Atlantic Forest (Cavalcanti 2015).

\section{Key for the species of Perichaena occurring in the Northeast Region of Brazil}

1. Sporophore plasmodiocarpic, occasionally accompanied by sporocarps 2

1. Sporophore sporocarpic, sessile or stalked 4

2. Capillitium-threads 3-4 $\mu \mathrm{m}$ diam., with long spines of up to $5 \mu \mathrm{m}$ in length

2. Capillitium-threads 1.5-2.5 $\mu \mathrm{m}$ diam., with warts or short spines of up to $2 \mu \mathrm{m}$ in length.

3. Peridium double; spore $10-15 \mu \mathrm{m}$ diam.

3. Peridium simple; spore 6-7 $\mu \mathrm{m}$ diam.

Sporocarp stalked to almost sessile, isolated or rarely in groups of two or three; dehiscence irregular, areola-shaped or in polygonal plates.

4. Sporocap sessile, densely grouped, seldom sparse, dehiscence circumscissile P. chrysosperma 5. Stalk developed, up to $0.7 \mathrm{~mm}$ long; dehiscence irregular apical or areola-shaped; spore (8) 9-10 $\mu \mathrm{m}$ diam.

5. Stalk very short, up to $0.35 \mathrm{~mm}$ long or absent; dehiscence by polygonal plates; spore 10-13.5 $\mu \mathrm{m}$ diam.

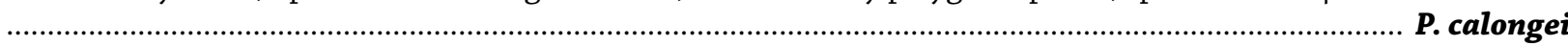
6. Sporotheca flattened, base fully supported by the substrate, dehiscence line on the bottom third, close to the base; spore spinose, 9-11 $\mu \mathrm{m}$ diam.

P. depressa

6. Sporotheca subglobose, base not fully supported by the substrate, average dehiscence line; spore faintly warted, 12-14 $\mu \mathrm{m}$ diam.

\section{Acknowledgments}

We acknowledge the Federal University of Pernambuco and the National Council for Technological and Scientific Development (CNPq), for financial support and a productivity grant awarded to L. H. Cavalcanti (CNPq/ PROTAX 248150054/2011-4; CNPq 305967/2009.6). We also thank the curators that allowed access to specimens deposited at the IPA, ICN, SP, UB, UFP, URM, TEPB and JPB Herbaria, and the staff of the 21 conservation units for support during field work.

\section{References}

Ab’SáberNA. 1999. Sertões e sertanejos: uma geografia humana sofrida. Estudos avançados 13: 7-59.

Alves MH, Costa AAA, Cavalcanti LH. 2010. Myxomycetes, state of Ceará, Northeastern Brazil. CheckList 6: 555-558.
Araújo JC, Lado C, Xavier-Santos S. 2015. Perichaena calongei (Trichiales): a new record of Myxomycetes from Brazil. Current Research in Environmental \& Applied Mycology 5: 357-361.

Basanta DW. 1998. Myxomycetes de la corteza de Quercus ilex. Anales del Jardin Botánico de Madrid 56: 3-14.

Basanta DW, Lado C, Estrada-Torres A, Stephenson SL. 2013. Biodiversity studies of Myxomycetes in Madagascar. Fungal Diversity 59: 55-83.

Bezerra ACC, Cavalcanti LH. 2007. Mixobiota corticícola de Terminalia catappa L. (Combretaceae). Sitientibus, Serie Ciências Biológicas 7: 154-160.

Bezerra ACC, Lima VXL, Tenorio JC, Cavalcanti LH. 2014. Myxomycetes from the State of Alagoas (Brazil) and notes on its distribution. Biotemas 27: 13-22.

Carvalho RCP, Sanchez M, Bezerra ACC, Santos LTP, Dianese JC. 2011. A micobiota da Reserva Ecológica do IBGE. In: Ribeiro ML. (ed.) Reserva Ecológica do IBGE. Rio de Janeiro, Coordenação de Recursos Naturais e Estudos Ambientais, IBGE. p 86-99.

Cavalcanti LH. 1974a. O gênero Perichaena Fries em Pernambuco. Rickia 6: 98-117.

Cavalcanti LH. 1974b. Mixomicetos corticícolas do cerrado de Emas (Pirassununga-São Paulo). MSc Thesis, Universidade de São Paulo, Brazil. 
Cavalcanti LH. 2015. Trichiales. In: Lista de Espécies da Flora do Brasil. Jardim Botânico do Rio de Janeiro. http://floradobrasil. jbrj. gov. br. Jun. 2015.

Cavalcanti LH, Fortes ST. 1994. Myxomycetes de Florianópolis (Santa Catarina - Brasil). Acta Botanica Brasilica 8: 65-75.

Cavalcanti LH, Fortes ST. 1995. Myxomycetes do Estado de Santa Catarina, Brasil. Broteria 67: 23-35.

Cavalcanti LH, Marinho MGV.1985. Myxomycetes da Paraíba I Trichiales. In: Sociedade Botânica do Brasil. Recife, Anais da VIII Reunião Nordestina de Botânica 1984. p 185-91.

Cavalcanti LH, Ponte MPMP, Mobin M. 2006a. Myxomycetes, State of Piauí, Northeast Brazil. CheckList 2: 70-74.

Cavalcanti LH, Santos EJ, Gomes NA. 1999. Myxomycetes do estado de Roraima, com especial referência para a estação Ecológica de Maracá (Amajarí - RR, Brasil). Acta Amazônica 29: 195-200.

Cavalcanti LH, Tavares HFM, Nunes ATF, Silva CF. 2006b. Mixomicetos In:Pôrto KC, Almeida-Cortez JC, Tabarelli M. (eds.) Diversidade Biológica e Conservação da Floresta Atlântica ao Norte do Rio São Francisco. Brasília, Ministério do Meio Ambiente (Série Biodiversidade 14). p 53-72.

Eliasson U. 1977. Recent advances in the taxonomy of Myxomycetes. Botaniska Notiser 130: 483-492.

Eliasson U. 2015. Review and remarks on current generic delimitations in the myxomycetes, with special emphasis on Licea, Listerella and Perichaena. Nova Hedwigia. (in press) DOI: 10. 1127/nova_hedwigia/2015/0283.

Estrada-Torres A, Basanta DW, Conde E, Lado C. 2009. Myxomycetes associated with dryland ecosystems of the Tehuacán-Cuicatlán Valley Biosphere Reserve, Mexico. Fungal Diversity 36: 17-56.

Farr ML. 1960. The Myxomycetes of the IMUR Herbarium with special reference to Brazilian species. Publicação do Instituto de Micologia 184: 1-54.

Farr ML. 1976. Myxomycetes. Flora Neotropica Monograph 16. New York, New York Botanical Garden.

Fiore-Donno AM, Clissmann F, Meyer M, Schnittler M, Cavalier-Smith T. 2013. Two-Gene Phylogeny of Bright-Spored Myxomycetes (Slime Moulds, Superorder Lucisporidia). PLoS One 8(5): 1-12. DOI: 10. 1371/journal. pone. 0062586

Góes A, Cavalcanti LH. 2002. Myxomycetes of the state of Bahia, Brazil: historical review and current situation. Mycotaxon 82: 335-342.

Gusmão LFP, Góes A, Cruz ACR. 2005. Fungos In: Juncá FA, Funch L, Rocha W. (eds.) Biodiversidade e Conservação da Chapada Diamantina. Brasília, Ministério do Meio Ambiente (Série Biodiversidade 13). p 225-242.

Härkönen M. 1981. Myxomycetes developed on litter of common Finnish trees in moist chamber cultures. Nordic Journal of Botany 1 : 791-794.

Hochgesand E, Gottsberger G. 1996. Myxomycetes from the State of São Paulo, Brazil. Boletim do Instituto de Botânica 10: 1-46.

Jahn E. 1902. Myxomycetenstudien. 2. Arten aus Blumenau (Brasilien). Berichte der Deutschen Botanischen Gesellschaft 20: 268-280.

Jahn E. 1919. Myxomycetenstudien 9. Bemerkungen über einige seltene order neue Arten. Berichte der Deutschen Botanischen Gesellschaft 36: 660-669.

Keller HW, Eliasson U. 1992. Taxonomic evaluation of Perichaena depressa and P. quadrata based on controlled cultivation, with additional observations on the genus. Mycological Research 96: 1085-1097.

Lado C. 2015. An on-line nomenclatural information system of Eumycetozoa. http://www. nomen. eumycetozoa. com. 15 Jun. 2015.

Lado C, Basanta DW. 2008. A review of Neotropical Myxomycetes (18282008). Anales del Jardín Botánico de Madrid 65: 211-254.

Lado C, Basanta DW, Estrada-Torres A, Garcia-Carvajal E. 2014. Myxomycete diversity of the Patagonian Steppe and bordering areas in Argentina. Anales del Jardín Botánico de Madrid 71: 1-35.
Lado C,Basanta DW, Estrada-Torres A, García Carvajal E, Aguilar M, Hernández-Crespo JC. 2009. Description of a new species of Perichaena (Myxomycetes) from arid areas of Argentina. Anales del Jardín Botánico de Madrid 66: 63-70.

Lado C, Pando F. 1997. Myxomycetes, I. Ceratiomyxales, Echinosteliales, Liceales, Trichiales. Flora Mycologica Ibérica. 2. Madrid,Consejo Superior de Investigationes Científicas. Real Jardín Botánico.

Lister A. 1925. A monograph of the Mycetozoa, 3rd. edn. London,British Museum of Natural History.

Lister A, Lister G. 1904. Notes on Mycetozoa. Journal of Botany 42: 129-140.

Liu C-H, Chang J-H, Yang F-H. 2007. Myxomycetous Genera Perichaena and Trichia in Taiwan. Botanical Studies 48: 91-96.

Maimoni-Rodella RC,Gottsberger G. 1980. Myxomycetes from the forest and the cerrado vegetation in Botucatu, Brazil: a comparative ecological study. Nova Hedwigia 34: 204-247

Martin GW, Alexopoulos CJ. 1969. The Myxomycetes. University of Iowa Press, Iowa.

McHugh R. 2009. Field and moist chamber collections of Paraguay myxomycetes. Karstenia 48: 49-56.

MI - Ministério da Integração Nacional. 2005. Nova delimitação do semi-árido brasileiro. Brasília, MI.

Mitchell DW, Moreno G,Lizárraga M. 2011. A new species of coprophilous Perichaena from New Mexico. Boletin de la Sociedad Micologica de Madrid 35: 103-108.

Novozhilov YK,Schnittler M. 2000. A new coprophilous species of Perichaena (Myxomycetes) from the Russian Arctic (the Taimyr Peninsula and the Chukchi Peninsula). Karstenia 40: 117-122.

Novozhilov YK, Stephenson SL. 2015. A new species of Perichaena (Myxomycetes) with reticulate spores from southern Vietnam. Mycologia 107:137-141.

Novozhilov YK, Zemlyanskaya IV,Schnittler M, Stephenson SL. 2008. Two new species of Perichaena (Myxomycetes) from arid areas of Russia and Kazakhstan. Mycologia 100: 816-822.

Poulain M, Meyer M, Bozonnet J. 2011. Les Myxomycètes. Sévrier,Fédération Mycologique et Botanique Dauphiné-Savoie.

Prado DE. 2003. As caatingas da América do Sul. In: Leal I, Tabarelli M, Silva JMC. (eds.) Ecologia e conservação da Caatinga. Recife, Ed. Universitária da UFPE. p 3-74.

Rodal MJN, Martins FR, Sampaio EVSB. 2008. Levantamento quantitativo das plantas lenhosas em trechos de vegetação de caatinga em Pernambuco. Revista Caatinga 21: 192-205.

Rojas C, Morales RE, Calderón I, Clerc P. 2013. First records of myxomycetes from El Salvador. Mycosphere 4: 1042-1051.

Ronikier A, Lado C, Basanta DW. 2013. Perichaena megaspora, a new nivicolous species of myxomycete from the Andes. Mycologia 105: 938-944.

Thiers BM. 2014. Index Herbariorum: A global directory of public herbaria and associated staff. New York, New York Botanical Garden.

Torrend C. 1908. LesMyxomycètes: Étude des espèces connues jusqu' ici. Broteria, série Botânica 7: 5-177.

Torrend C. 1915. Les Myxomycetes du Brésil, connus jusqu'ici. Broteria 13: $72-88$

Torrend C. 1916. Os Myxomycetes dos arredores da Bahia. In: Salvador, Anais do $5^{\circ}$ Congresso Brasileiro de Geografia. p. 484-492.

Uchoa CAM,Tabarelli M. 2002. Diagnóstico e Estratégia de Conservação do Centro de Endemismo Pernambuco. Recife, Conservation International do Brasil.

Walker L, Leontyev D, Stephenson SL. 2015. Perichaena longipes, a newmyxomycetes from the Neotropics. Mycologia 107: 1012-1022.

Wang Q, LiYu, Bai JK. 2000. Trichiales Myxomycetes from China I. Perichaena. Mycosystem 19: 163.

Yamamoto Y, Chen SL, Degawa Y, Hagiwara H. 2002. Myxomycetes from Yunnan Province, China. Bulletin of the National Science Museum Tokyo 28: 61-76. 